\title{
Progranulin Protects Rat Testis From Ischaemic Reperfusion Injury
}

\author{
EMAN R. ABOZAID, M.D.* and NAGLAA A. AHMED, M.D.*,** \\ The Department of Physiology*, Faculty of Medicine, Zagazig University, Egypt and Physiology Department**, \\ Faculty of Medicine, Najran University, KSA
}

\begin{abstract}
Background: Ischemic reperfusion (I/R) damage of the testis is a common problem, it is mainly caused by testicular torsion and detorsion. Progranulin (PGRN) has been reported to have prominent anti-inflammatory and protective effects on $\mathrm{I} / \mathrm{R}$ injury in the heart, brain and kidney, however, its effects on testicular I/R lesion have not been evaluated.

Aim of Study: To examine the effects of progranulin on rat testicular ischaemia/reperfusion induced by torsion/ detorsion and the possible underlying mechanisms.

Material and Methods: In this study, rats were divided into 4 groups: (i) Sham; (ii) Testicular ischemia/reperfusion (I/R), $2 \mathrm{~h}$ of ischemia followed by $6 \mathrm{~h}$ of reperfusion; (iii) $\mathrm{I} / \mathrm{R}$ treated by PGRN $(0.01 \mathrm{~g} / \mathrm{g} / \mathrm{t})$ administered $1.5 \mathrm{~h}$ after the induction of ischaemia. (iv) I/R treated by PGRN (0.1 $\mathrm{g} / \mathrm{t})$ administered $1.5 \mathrm{~h}$ after development of ischemia. At the end of the study, some testicular oxidative stress markers, inflammatory, apoptotic markers and serum testosterone were measured, in addition to histopathologic study.
\end{abstract}

Results: Significant decreases in serum testosterone levels, testicular superoxide dismutase (SOD) and glutathione peroxidase (Gpx) activity with increase in tissue malondialdehyde (MDA) were observed in I/R group when compared with controls. These antioxidant levels were increased in PGRN treated groups with significant decrease in MDA levels. While an increase in tumor necrosis factor-alpha (TNF- $\alpha$ ), IL-1 $\beta$ caspase- 8 and caspase- 3 levels were found in the torsion/ detorsion group, significant decrease in the levels of these inflammatory cytokines and apoptotic markers were observed in PRGR treated groups in a dose dependent maner.

Conclusion: These results demonstrate that PGRN significantly produced protective effects on testicular tissue damage through antioxidant, anti-inflammatory and antiapoptotic mechanisms.

Key Words: Progranulin - Ischaemia - Reperfusion - Testis.

\section{Introduction}

TESTICULAR torsion is a common emergency that is primarily induced by torsion of the spermatic cord in infants, children, and adolescents. Its incidence has been estimated at 1 out of 160 to 4000

Correspondence to: Dr. Eman R. Abozaid,

E-Mail: eman.zaher.2005@gmail.com males per year by 25 years of age [1-3]. Ischaemia followed by reperfusion (I/R), which occurs as a result of testicular torsion followed by testicular detorsion (T/D), results in testicular injury. Oxygen amounts are less than metabolic needs after ischaemia, and death of germ cells occurs due to oxygen lack resulting in accumulation of noxious metabolites in the cells [4]. In the period of reperfusion, there is great increase in reactive nitrogen species and reactive oxygen species [5]. Reperfusion is essential for survival of injured tissues, yet, it greatly exagerates cell and tissue damage [6]

Progranulin (PGRN) is considered to be an important growth factor with many physiological functions. PGRN has anti-inflammatory action, this is due to its suppressive effect on tumor necrosis factor $\alpha(\mathrm{TNF}-\alpha)$ transmission and also its inhibitory effect on neutrophil degranulation [7-8]

In vitro and in vivo studies have demonstrated that PGRN has significant role in diverse physiological processes. This protein participates in the growth stimulation in early embryogenesis, wound healing, inflammation, angiogenesis, bone and cartilage development [9-13]. It is also considered to be an adipokine which is involved in obesity, insulin resistance, and rheumatic disease [14] Recently, it was reported that PGRN binds TNF receptors and suppresses its inflammatory effect [15]. In the central nervous system (CNS), PGRN has been reported to function as a neurotrophic factor [16] with immunomodulatory actions [17-19] and anti-inflammatory properties $[\mathbf{2 0 , 2 1 ]}$ and has a neuroprotective effect in several injury modalities, including oxygen glucose deprivation [22] and oxidative injury [23]

In the present study, we examined whether PGRN has potential ameliorative effects against testicular I/R injury, and also investigated the underlying mechanisms. 


\section{Material and Methods}

Animals: This study was conducted in the scientific and medical research center (ZSMRC) in Faculty of Medicine, Zagazig University in the period from ${ }^{1 \text { st }}$ January to 20 th of April 2019, we used in this study a total of 48 adult male albino Wistar rats (weighing 170-200g) (the animals were around 12 weeks old). This study protocol was approved by the Institutional review Board and Ethics Committee of Medicine Faculty, Zagazig University. The experimental procedures were performed according to the guide for the use and care of laboratory animals, published by the Institute of Laboratory Animal Resources. The rats were housed in standard, plastic cages on sawdust bedding in an air-conditioned room at $22^{\circ} \mathrm{C}$ under controlled light conditions (14/10-h light/dark cycle). Standard rat chow and tap water were provided ad libitum.

Experimental design: Animals were divided into equal 4 groups. Group I: A sham operated (control group), rats received Phosphate-Buffered Saline (PBS) $1 \mathrm{ml} / \mathrm{rat}$. Group II: Testis torsion was induced for $2 \mathrm{~h}$ then testicular detorsion was applied for $6 \mathrm{~h}$, (IR group). 1.5h after torsion, rats received Phosphate-Buffered Saline (PBS) 1 $1 \mathrm{ml} /$ rat. Groups III and IV (PGRN treated groups): Testis torsion was induced for $2 \mathrm{~h}$., after testicular torsion by $1.5 \mathrm{~h}$., rats received recombinant murine PGRN (SRP6059-10UG sigma-Aldrich). (0.01 gand $0.1 \mathrm{~g} / \mathrm{r})$. PGRN was administered intraperitoneally dissolved in $1 \mathrm{ml} \mathrm{PBS} /$ rat respectively, dose selected according to preliminary study, then, testicular detorsion was applied for $6 \mathrm{~h}$.

Surgical procedure: As described by Dogan et al. [24], the animals were anaesthetized by $25 \mathrm{mg} /$ $\mathrm{kg}$ thiopental sodium injected intraperitonealy. In the sham group, the testis was localized through a left-sided scrotal incision, and then the incision was sutured with $4 / 0$ silk without additional intervention. In the remaining groups (ischemia / reperfusion), a vertical $2 \mathrm{~cm}$ incision was performed in the left scrotum along the midline area. Then the left testes were rotated $720^{\circ}$ clockwise with the tunica vaginalis and spermatic cord, the ischemia was applied for period of $2 \mathrm{~h}$.

At the end of experiment, all animals were sacrificed using large dose of thiopental sodium $(60 \mathrm{mg} / \mathrm{kg})$, and then withdrawal of blood samples were done using intracardiac method. A part of testicular tissue was fixed in formalin solution $(10 \%)$ for histopathological examination, whereas, most of testicular tissues were carried to a molecular laboratory where they were kept at $80^{\circ} \mathrm{C}$ for molecular and biochemical study.

Histological procedure: After fixation of testicular tissue in formalin, each tissue sample was routinely processed to be embedded in paraffin. After that, sections were taken from testicular tissue 5-mm each and then stained with Hematoxylin an Eosin and photos were taken by a digital camera attached to light microscope.

\section{Biochemical investigations:}

Serum free testostosterone level: Serum free testostosterone level was measured using testosterone ELISA kit (BioCheck, Dr. Foster City, CA 94405) as described by [25]

$S O D, G p x$ and MDA: After the surgical procedures, approximately $100 \mathrm{mg}$ of ground testicular tissue was homogenized in $1 \mathrm{ml}$ of phosphate buffered saline homogenate in an Eppendorf tube using the Tissue Lyser II and then centrifuged. SOD [26], Gpx [27] and MDA [28] levels from each sample supernatant and standards were measured at room temperature in duplicate according to the modified methods of the ELISA reader as described previously [29]. Results for MDA, SOD and GPX were expressed as $\mathrm{nmol} / \mathrm{mg}$ protein, $\mathrm{U} / \mathrm{mg}$ protein and $\mathrm{U} / \mathrm{mg}$ protein respectively.

Measurement of testicular inflammatory biomarkers: IL-1 $\beta$ and TNF- $\alpha$ concentrations were quantified according to the manufacturer's instructions and guidelines using an ELISA kit specific for the rat cytokines (Bio diagnostic, Egypt kits) as previously described [30].

Evaluation of apoptosis markers: Activities of caspases- 8 and caspases- 3 were evaluated using their specific colorimetric assays following their manufacturer's recommendations (Sigma Aldrich, St. Louis, MO, USA).

\section{Statistical analysis:}

In our study we used IBM SPSS version 24 (SPSS Inc., Chicago, IL, United States) software. Results are presented as means and standard deviation. Comparisons between groups were performed with one-way ANOVA and LSD post hoc test, Significance was accepted at $p<0.05$.

\section{Results}

Histological investigations: In the sham group (Fig. 1 a) the seminiferous tubules appears normal, with no change in histological structure. In I/R group (Fig. 1b), there is extensive edema in the interstitial area of seminiferous tubules and their 
boundaries showed great abnormality. The edema and degeneration in spermatogonia of I/R group were greatly decreased in the third group treated with PGRN $0.01 \mathrm{mg} / \mathrm{kg}$, group (Fig. 1c). In the fourth group, (Fig. 1d), the thickness of the germinal epithelium was more clearly seen than in I/R + PGRN $0.01 \propto \mathrm{g} /$ rat. Moreover, also in the fourth group, mature spermatids were detected near the lumen of seminiferous tubules.

Biochemical parameters: Serum level of free testosterone was decreased in I/R group compared to control, but this effect was improved by PGRN $(p<0.001)$ (Table 1). In addition, testicular levels of SOD and Gpx were decreased in I/R group $(p<0.001)$, however, MDA, TNF- $\alpha$, IL-1 (3, caspase 3 and 8 activities were increased in I/R group $(p<0.001)$ when compared to the sham group. In group III, PGRN $0.01 \propto \mathrm{g} / \mathrm{rat}$ administration were found to significantly increase SOD and Gpx activity $(p<0.001)$. While significantly decreased the testicular levels of MDA, TNF- $\alpha$, caspase 3 ( $p<$ $0.001)$, caspase 8 and IL-1 $(3(p<0.01)$. In group IV, PGRN $0.1 \propto \mathrm{g} /$ rat administration was found to be more effective in reversing the effect of $I / R$ injury on histopathlogical level and biochemical level, the higher dose led to significant improvement in all biochemical parameters $(p<0.01)$ when compared to lower dose and decreasing values near the control, by another words, the differences in the values of serum testesteron, testicular SOD, Gpx, MDA, TNF- $\alpha$, IL-1 ( 3 , caspase 3 and 8 between the sham and PGRN $0.1 \propto \mathrm{g} /$ rat-treated group were not significant).

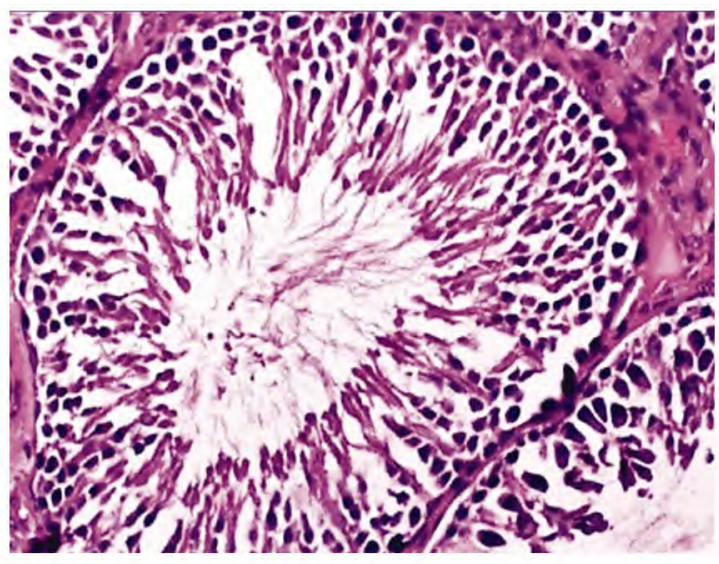

(A)

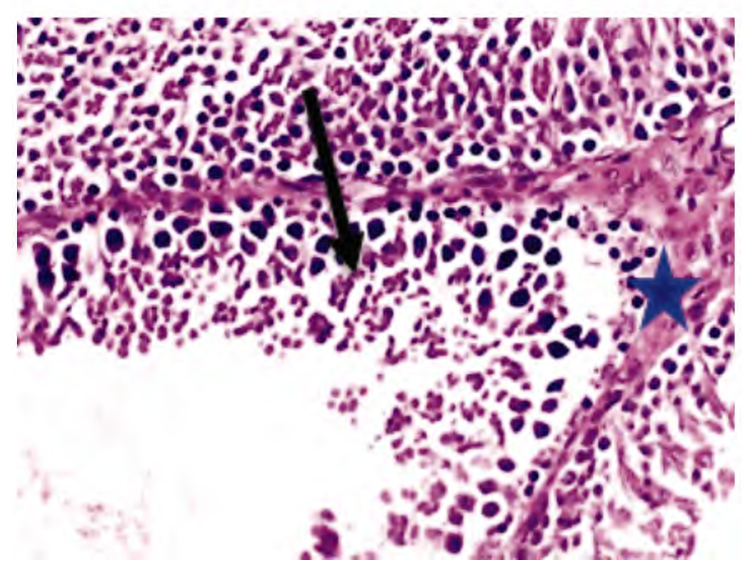

(C)

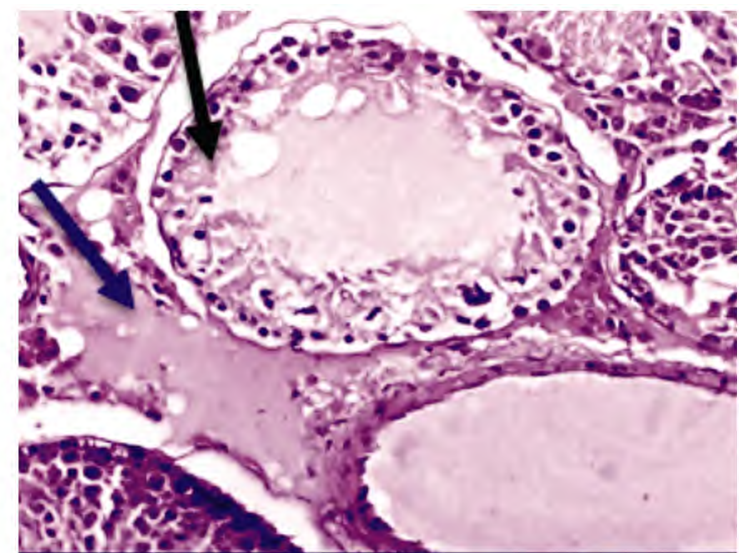

(B)

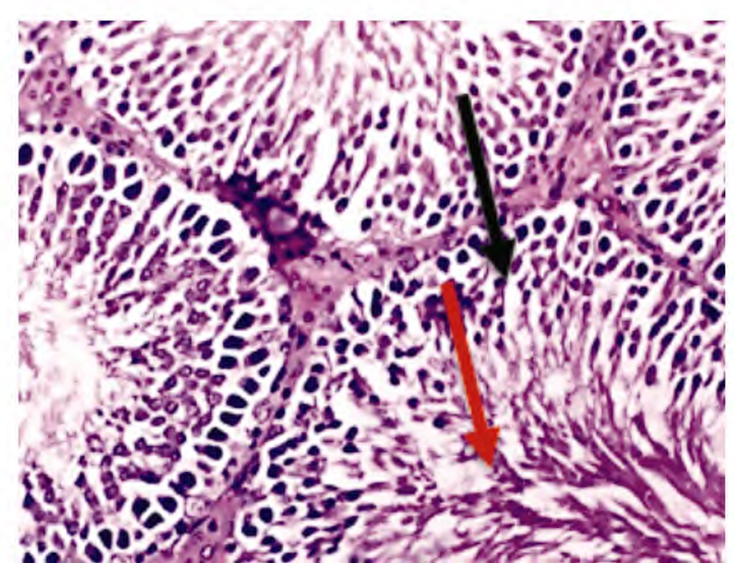

(D)

Fig. (1): Showing section in testis: (A) testis of control group showing normal spermatids, spermatogonia and interstitial tissue. (B) I/R injury showing marked degeneration and vacuolization of spermatogonia (black arrow) and interstitial edema (blue arrow). (C) Section in testis with I/R injury treated by PGRN $0.01 \propto \mathrm{g} / \mathrm{rat}$, showing moderate degeneration (black arrow) of some spermatogonia with no interstitial edema. (D) Section in I/R testis treated with PGRN $0.1 \propto \mathrm{g} /$ rat showing mild degeneration of some germ cell (blue star), preservation of spermatogonia (black arrow) with appearance of spermatids in some tubules (red arrow) (H\&E X400). 
Table (1): Serum free testosterone level and testicular TNF- $\alpha$, IL-1 $\beta$, MDA, GpX, SOD, and caspase-8 and caspase- 3 in all studied groups.

\begin{tabular}{|c|c|c|c|c|}
\hline Group & Group I & Group II & Group III & Group IV \\
\hline $\begin{array}{l}\text { Free testosterone }(\mathrm{ng} / \mathrm{ml}) \\
\mathrm{X} \pm \mathrm{SD} \\
p \text {-value of LSD }\end{array}$ & $3.72 \pm 0.3$ & $\begin{array}{l}2.02 \pm 0.17 \\
p<0.001^{*}\end{array}$ & $\begin{array}{l}3.11 \pm 0.23 \\
p<0.001 * \#\end{array}$ & $\begin{array}{l}3.51 \pm 0.49 \\
p<0.001 \# \\
p<0.01 \$\end{array}$ \\
\hline $\begin{array}{l}T N F \alpha(p g / m g \text { protein }): \\
\mathrm{X} \pm \mathrm{SD} \\
p \text {-value of LSD }\end{array}$ & $28.01 \pm 3.13$ & $\begin{array}{l}58.38 \pm 4.24 \\
p<0.001^{*}\end{array}$ & $\begin{array}{l}33.51 \pm 3.35 \\
p<0.001 * \#\end{array}$ & $\begin{array}{l}29.51 \pm 1.35 \\
p<0.001 \# \\
p<0.01 \$\end{array}$ \\
\hline $\begin{array}{c}I L-1 \beta(p g / m g \text { protein }): \\
\mathrm{X} \pm \mathrm{SD} \\
p \text {-value of LSD }\end{array}$ & $30.33 \pm 3.47$ & $\begin{array}{l}49.3 \pm 4.74 \\
p<0.001^{*}\end{array}$ & $\begin{array}{l}41.10 \pm 3.77 \\
p<0.01 \# \\
p<0.001 *\end{array}$ & $\begin{array}{l}34.04 \pm 2.07 \\
p<0.001 \# \\
p<0.05 \$\end{array}$ \\
\hline $\begin{array}{l}\text { MDA (nmol/mg protein }): \\
\mathrm{X} \pm \mathrm{SD} \\
p \text {-value of LSD }\end{array}$ & $110.37 \pm 6.26$ & $\begin{array}{l}190.26 \pm 16.93 \\
p<0.001^{*}\end{array}$ & $\begin{array}{l}153.91 \pm 7.19 \\
p<0.001 \# \\
p<0.01^{*}\end{array}$ & $\begin{array}{l}123.91 \pm 7.19 \\
p<0.001 \# \\
p<0.05 \$\end{array}$ \\
\hline $\begin{array}{c}G P X(U / m g \text { protein }): \\
\mathrm{X} \pm \mathrm{SD} \\
p \text {-value of LSD }\end{array}$ & $20.17 \pm 3.28$ & $\begin{array}{l}11.92 \pm 2.22 \\
p<0.001^{*}\end{array}$ & $\begin{array}{c}15.91 \pm 1.17 \\
p<0.001 \#\end{array}$ & $\begin{array}{l}18.59 \pm 1.27 \\
p<0.001 \# \\
p<0.01 \$\end{array}$ \\
\hline $\begin{array}{c}\text { SOD (U/mg protein }): \\
\mathrm{X} \pm \mathrm{SD} \\
p \text {-value of LSD }\end{array}$ & $68.58 \pm 4.55$ & $\begin{array}{l}30.85 \pm 5.17 \\
p<0.001^{*}\end{array}$ & $\begin{array}{l}51.30 \pm 7.36 \\
p<0.001 * \#\end{array}$ & $\begin{array}{l}63.30 \pm 5.3 \\
p<0.001 \# \\
p<0.05 \$\end{array}$ \\
\hline $\begin{array}{l}\text { Caspase- } 8(\mathrm{nmol} / \mathrm{min} / \mathrm{ml}) \\
\mathrm{X} \pm \mathrm{SD} \\
p \text {-value of LSD }\end{array}$ & $0.31 \pm 0.04$ & $\begin{array}{l}3.08 \pm 0.41 \\
p<0.001^{*}\end{array}$ & $\begin{array}{l}1 . \pm 0.31 \\
p<0.01 \# \\
p<0.001 *\end{array}$ & $\begin{array}{l}1.6 \pm 0.31 \\
p<0.001 \# \\
p<0.05 \$\end{array}$ \\
\hline $\begin{array}{l}\text { Caspase-3 }(\mathrm{nmol} / \mathrm{min} / \mathrm{ml}) \\
\mathrm{X} \pm \mathrm{SD} \\
p \text {-value of LSD }\end{array}$ & $5.18 \pm 0.60$ & $\begin{array}{l}12.53 \pm 1.32 \\
p<0.001^{*}\end{array}$ & $\begin{array}{l}8.8 \pm 0.83 \\
p<0.001 * \#\end{array}$ & $\begin{array}{l}6.33 \pm 0.73 \\
p<0.001 \# \\
p<0.01 \$\end{array}$ \\
\hline
\end{tabular}

* Significant versus group I. ～\# Significant versus group II. \$ Significant versus group III.

\section{Discussion}

Testicular ischemia is one of the emergency conditions which require immediate detorsion within 4-6 hours to avoid loss of testicular function [30]. If testicular torsion is corrected after longer time period, testicular atrophy develops subsequently [31].

In the current study, ischemia (torsion) followed by reperfusion (detorsion) showed testicular damage which led to decrease in serum testosterone level. These results are similar to that showed by other studies $[\mathbf{3 2}, \mathbf{3 3}]$.

According to our histopathological findings, in our I/R model, we noticed extensive degeneration of germ cells, extensive edema between the cells, hyalinization of the interstitial area and we also noticed great increase in extracellular material in the vascular walls inside seminiferous tubules. Our results showed that PGRN ameliorates this effect of testis $\mathrm{I} / \mathrm{R}$ with dose dependent improvement in inflammatory and apoptotic conditions of testis. Our results are in agreement with many studies showed that PGRN exerted ameliorative effects against I/R-induced inflammation in different models as heart, hypercholesterolemia and decrease inflammation in asthma and colitis model [7-34-37]

During I/R in testis the damage occurs due to free radicals. A part of the prominent features which may be responsible for pathological changes occurring in case of I/R damage are changes in levels of inflammatory cytokines, nonenzymatic oxidants, and antioxidant enzymes. One of these parameters is MDA, which is a final product of 
lipid peroxidation. Another parameter is SOD which is considered to have a great role in protecting cells against the undesirable effects of superoxide radicals [38].

SOD decreased in our model of I/R group. Similar to our findings, some studies showed that SOD levels were diminished after testicular torsion and detorsion $[39,40]$. However, PGNR increase SOD levels in dose dependent manner. In other studies examining effect of ischemia and reperfusion on different tissues, results of these studies showed that PGRN increased SOD levels in I/R groups. Gpx is an antioxidant enzyme that we evaluated in this study, Gpx levels decreased significantly in I/R groups when compared to the control group, on the other hand treatment with PGRN significantly elevated Gpx levels. In agreement with our results, Grace reported that Gpx levels were lowered in testicular torsion detorsion model [41].

TNF- $\alpha$ and IL- $1 \beta$ are cytokine which intermediates natural immunity after reperfusion [42]. It has been reported that TNF- $\alpha$ has a great role in development of vascular injury and in appearance of endothelium adhesion molecules [43]. Thus, we measured TNF- $\alpha$ levels in the testicular tissue in our study. Our results showed that levels of TNF$\alpha$ significantly elevated in second group. Our results suggested that TNF- $\alpha$ and IL- $1 \beta$ have important roles in testis damage in agreement with the result of Lin et al. [44]. Our results also showed that TNF- $\alpha$ and IL- $1 \beta$ levels significantly decreased in both treatment groups with more improvement with higher dose of PGRN when compared to the lower dose group.

In addition, we examined the potential role of PGRN on testicular I/R injury through measuring MDA, which is a final product of lipid peroxidation. We found that MDA levels significantly increased in testicular I/R groups and there was a significant lowering in MDA levels in PGRN treated groups during I/R damage, the reduction in MDA was noticed to be a dose dependent, this result is in agree with the study of Wei et al. [30].

Necrosis and apoptosis may play significant roles in I/R cellular injury, they take place simultaneously in oxidative conditions [45]. Apoptosis plays role in maintaining homeostasis in spermatogenesis, however, testicular I/R injury usually leads to marked spermatogenic cell apoptosis, which can cause impaired testicular function and infertility [46].
Caspase- 3 is considered to be an inactive zymogen and the convergence point of multiple apoptotic pathways. Its activation is an irreversible step to induce cell apoptosis $[47,48]$. High levels of caspase- 8 and caspase- 3 were increased in testicular I/R group in our study, but their levels were reduced by PGRN treatment in the both treated I/R groups in a dose dependent manner. And in line with this result, Bo et al., [49] showed that PGRN inhibits neuronal cell death in rats after subarachnoid hemorrhage and suggested a possible mechanism via sortilin 1-mediated and Akt-related antiapoptosis pathway.

Conclusion: We concluded that PGRN has protective effects on testicular I/R damage. We found that the injection of PGRN has antioxidant effect by decreasing free radicals and increasing antioxidants. Moreover, PGRN has antiinflammatory effect through decreasing inflammatory markers and preventing inflammation-induced tissue damage from being exaggerated, in addition, it inhibits apoptosis by decreasing levels of caspase3 and -8 . All these effects are in harmony with improvement in histopathological tissue damage. This improvement is correlated with increasing the dose of PGRN. These results suggested that PGRN may be used in future for treatment of testicular torsion/ detorsion damage, in the clinical feild. Further experimental and clinical studies are needed for confirming the possible mechanism/s and effective dose of PGRN.

Declaration of interest statement: The authors declare that there is no conflict of interests regarding the publication of this paper.

\section{Acknowledgment:}

We are grateful to the members of Zagazig Scientific and Medical Research Center (ZSMRC) in Zagazig University, Egypt for its support. Moreover, we are thankful to dr Mona Mostafa Ahmed Lecturer of Pathology, Faculty of Medicine, Zagazig University, for her role in the proper examination and interpretation of the histopathological data of this study. Finally, we are grateful to Prof. Dr. Abeer A. Khalefa, professor of physiology, Faculty of Medicine, Zagazig University, Egypt, for her help and support.

\section{References}

1- BARADA J.H., WEINGARTEN J.L. and CROMIE W.J.: Testicular salvage and age related delay in the presentation of testicular torsion. J. Urol., 142: 746-8, 1989.

2- RINGDAHL E. and TEAGUE L.: Testicular torsion. Am. Fam Physician, 74: 1739-43, 2006. 
3- WAMPLER S.M. and LLANES M.: Common scrotal and testicular problems. Prim Care, 37: 613-26, 2010.

4- MOGILNER J.G., LURIE M., CORAN A.G., NATIV O., SHILONI E. and SUKHOTNIK I.: Effect of diclofenac on germ cell apoptosis following testicular ischemiareperfusion injury in a rat. Pediatr. Surg. Int., 22: 99-105, 2006.

5- LYSIAK J.J., NGUYEN Q.A.T. and TURNER T.T.: Peptide and nonpeptide reactive oxygen scavengers provide partial rescue of the testis after torsion. J. Androl., 23: 400-409, 2002.

6- ABELLA V., PINO J., SCOTECE M., et al.: Progranulin as a biomarker and potential therapeutic agent. Drug Discov Today, 22: 1557-64, 2017.

7- POGONOWSKA M., PONIATOWSKI 'L A., WAWRZYNIAK A. and KRÓLIKOWSKA K.: The role of progranulin (PGRN) in the modulation of anti-inflammatory response in asthma. Cent. Eur. J. Immunol., 44 (1): $97-$ 101, 2019.

8- TIAN R., LI Y. and YAO X.: PGRN suppresses inflammation and promotes autophagy in keratinocytes through the $\mathrm{Wnt} /[3$-catenin signaling pathway. Inflammation, 39: 1387-94, 2016.

9- HE Z., ONG C.H.P., HALPER J. and BATEMAN A.: Progranulin is a mediator of the wound response. Nature Medicine, 2003.

10-NERMEEN A. FOUADA, MAHA H. NASSRA, HANAN M. FATHIA, OTHMAN M. ZAKIB, AHMED A. NEGMCD and SOHA H. SENARAA: Potential value of serum progranulin as an activity biomarker in rheumatoid arthritis patients: Relation to musculoskeletal ultrasonographic evaluation. The Egyptian Rheumatologist., 41 (2): 93-7, 2019.

11- TOH H., CAO M., DANIELS E. and BATEMAN A.: Expression of the growth factor progranulin in endothelial cells influences growth and development of blood vessels: A novel mouse model. PloS One, 2013.

12- FENG J.Q., GUO F.J., JIANG B.C., ZHANG Y. and FRENKEL S.: Granulin epithelin precursor: A bone morphogenic protein 2-inducible growth factor that activates Erk1/2 signaling and JunB transcription factor in chondrogenesis. The FASEB Journal, 2010.

13- XU K., ZHANG Y., ILALOV K., CARLSON C.S. and FENG J.Q.: Cartilage oligomeric matrix protein associates with granulin-epithelin precursor (GEP) and potentiates GEP-stimulated chondrocyte proliferation. Journal of Biological, 2007.

14- YAPANOGLU T., OZKAYA F., YILMAZ A.H., et al.: Effect of etoricoxib on experimental oxidative testicular ischemia-reperfusion damage in rats induced with torsiondetorsion. Korean J. Physiol. Pharmacol., 21 (5): 457-64, 2017.

15- TANG W., LU Y., TIAN Q.Y., ZHANG Y., GUO F.J. and LIU G.Y.: The growth factor progranulin binds to TNF receptors and is therapeutic against inflammatory arthritis in mice, 2011.

16- CHUNYU ZHAO and ANDREW BATEMAN: Progranulin protects against the tissue damage of acute ischaemic stroke. BRAIN, 138: 1766-177, 2015.
17- TOH H., CHITRAMUTHU B.P., BENNETT H.P. and BATEMAN A.: Structure, function, and mechanism of progranulin; the brain and beyond. J. Mol. Neurosci., 45: 538-48, 2011.

18- GASS J., LEE W.C., COOK C., FINCH N., STETLER C., JANSENWEST K., LEWIS J., LINK C.D., RADEMAKERS R., NYKJAER A. and PETRUCELLI L.: Progranulin regulates neuronal outgrowth independent of sortilin. Mol. Neurodegener, 7: 33, 2012.

19- DeMUYNCK L., HERDEWYN S., BEEL S., SCHEVENEELS W., VAN DEN BOSCH L., ROBBERECHT W. and VAN DAMME P.: The neurotrophic properties of progranulin depend on the granulin $\mathrm{E}$ domain but do not require sortilin binding. Neurobiol. Aging, 34: 2541-47, 2013.

20- KESSENBROCK K., FRÖHLICH , SIXT M., LÄMMERMANN T., PFISTER H., BATEMAN A., BELAAOUAJ A., RING J., OLLERT, FÄSSLER R. and JENNE D.E.: Proteinase 3 and neutrophil elastase enhance inflammation in mice by inactivating antiinflammatory progranulin. $\mathrm{J}$. Clin. Invest, 118: 2438-2447, 2008.

21- ANDREW D. NGUYEN, THI A. NGUYEN, RAJESH K SINGH, DELPHINE EBERLÉ, JIASHENG ZHANG, JESS PORTER ABATE, ANATALIA ROBLES, SUNEIL KOLIWAD, et al.: Progranulin in the hematopoietic compartment protects mice from atherosclerosis. Atherosclerosis, Vol. 277: p145-154, 2018.

22- XU J., XILOURI M., BRUBAN J., SHIOI J., SHAO Z., PAPAZOGLOU I., VEKRELLIS K. and ROBAKIS N.K.: Extracellular progranulin protects cortical neurons from toxic insults by activating survival signaling. Neurobiol. Aging, 32: 2326e5-e16, 2011.

23- MARTENS L., ZHANG J., BARMADA S.J., ZHOU P., KAMIYA S. and SUN B.: Progranulin deficiency promotes neuroinflammation and neuron loss following toxininduced injury. J. Clin. Invest, 122: 3955-59, 2012.

24- DOGAN1 C., HALICI1 Z., TOPCU2 A., CADIRCI1 E., KARAKUS3 E., BAYIR4 Y. and SELLI J.: Effects of amlodipine on ischaemia/reperfusion injury in the rat testis. Andrologia, 48: 441-52, 2016.

25- TIETZ N.: Clinical Guide to Laboratory Tests, ${ }^{3 \text { rd }}$ Ed., W.B. Saunders Company, Philadelphia, 509-80, 1995.

26- SUN Y., OBERLEY L.W. and LI Y.: A simple method for clinical assay of superoxide dismutase. Clin. Chem. 34: 497-500, 1988.

27- SEDLAK J. and LINDSAY R.H.: Estimation of total, proteinbound, and nonprotein sulfhydryl groups in tissue with Ellman's reagent. Anal Biochem., 25: 192-205, 1968.

28- OHKAWA H., OHISHI N. and YAGI K.: Assay for lipid peroxides in animal tissues by thiobarbituric acid reaction. Anal Biochem., 95: 351-8, 1979.

29- AKPINAR E., HALICI Z., CADIRCI E., BAYIR Y., KARAKUS E., CALIK M., TOPCU A. and POLAT B.: What is the role of renin inhibition during rat septic conditions: Preventive effect of aliskiren on sepsis-induced lung injury. Naunyn Schmiedebergs Arch. Pharmacol., 387: 969-78, 2014

30- WEI F., ZHANG Y., JIAN J., et al.: PGRN protects against colitis progression in mice in an IL-10 and TNFR2 dependent manner. Sci. Rep., 4: 7023, 2014. 
31- LIAN B., ONG C., CHIANG L., RAI R. and NAH S. Factors predicting testicular atrophy acer testicular salvage following torsion. European Journal of Pediatric Surgery, 26 (1): 17-21, 2016.

32- NING J., LI W., CHENG F., RAO T., WEI-YU M., RUAN Y., YUAN R., ZHU S., ZHANG X., DU Y. and XIAo C.: The protective effects of GYY4137 on testicular torsion/ detorsion injury in rats. Int. J. Clin. Exp. Med., 11 (4): 3387-95, 2018.

33- BAYATLI F., AKKUS D., KILIC E., SARAYMEN R. and SONMEZ M.F.: The protective effects of grape seed extract on MDA, AOPP, apoptosis and eNOS expression in testicular torsion: An experimental study. World J. Urol., 31: 615-22, 2013.

34- DUSMEZ D., CENGIZ B., YUMRUTAS O., DEMIR T., OZTUZCU S., DEMIRYUREK S., TUTAR E., BAYRAKTAR R., BULUT A., SIMSEK H., DAGLI S.N., KILIC T. and BAGCI C.: Effect of verapamil and lidocaine on TRPM and NaV 1.9 gene expressions in renal ischemia-reperfusion. Transplant Proc., 46: 33-9, 2014.

35- TAKHTFOOLADI M.A., SHAHZAMANI M., TAKHTFOOLADI H.A., MOAYER F. and ALLAHVERDI A.: Effects of light-emitting diode (LED) therapy on skeletal muscle ischemia reperfusion in rats. Lasers Med. Sci., 30 (1): 311-6, 2015.

36- AL-AHMED A., LASHEEN N. and EL-ZAWAHRY K . GINKGO BILOBA: Ameliorates Subfertility Induced by Testicular Ischemia/Reperfusion Injury in Adult Wistar Rats: A Possible New Mitochondrial Mechanism. Oxidative Medicine and Cellular Longevity, Volume, Article ID 6959274. 2016.

37- BESSET V., Le MAGUERESSE BATTISTONI B., COLLETTE J. and BENAHMED M.: Tumor necrosis factor alpha stimulates insulin-like growth factor binding protein 3 expression in cultured porcine Sertoli cells. Endocrinology, 137: 296-303, 1996.

38- STEPHAN J.P., SYED V. and JEGOU B.: Regulation of Sertoli cell IL-1 and IL-6 production in vitro. Mol. Cell. Endocrinol., 134: 109-18, 1997.

39- BENBRAHIM-TALLAA L., BOUSSOUAR F., REY C. and BENAHMED M.: Tumor necrosis factor- a inhibits glutathione S-transferasealpha expression in cultured porcine Sertoli cells. J. Endocrinol., 175: 803-12, 2002.
40- ABBAS A.K., LICHTMAN A.H. and POPER J.S.: Cellular and Molecular Immunology. WB Saunders Company, Philadelphia.

41- GRACE P.A.: Ischaemia-reperfusion injury. Br. J. Surg., 81: 637-47, 1994

42- CHI K., ZHANG W., WANG G., et al.: Comparison of intraperitoneal and intraepididymal quercetin for the prevention of testicular torsion/detorsion-induced injury. Urology, 99: 106-11, 2017.

43- De CESARIS P., STARACE D., RICCIOLI A., PADULA F., FILIPPINI A. and ZIPARO E.: Tumor necrosis factoralpha induces interleukin- 6 production and integrin ligand expression by distinct transduction pathways. J. Biol. Chem., 273 : 7566-757143, 1998.

44- LIN E., LOWRY S.F. and CALVANO S.E.: The systemic response to injury. In: Principles of Surgery. Schwartz SL (ed). (7 edn) McGraw-Hill, New York, NY, 29, 1999.

45- ASMA MOHAMMED ALYAHYA, ABEER AL MASRI, EMAN ELETER and AHMED ALHERSI: Progranulin attenuates in vivo acute myocardial ischemia/reperfusion injury in a rat model of hypercholesterolemia. Atherosclerosis, Vol. 263, e148-e49, 2017.

46- FILHO D. W., TORRES M.A., BORDIN A.L., CREZCYNSKI-PASA T.B. and BOVERIS A.: Spermatic cord torsion, reactive oxygen and nitrogen species and ischemiareperfusion injury. Mol. Aspects Med., 25: 199-210, 2004.

47- FENG T., SHI P., GHAVAMIAN A., et al.: Progranulin protects against endotoxin-induced acute kidney injury by downregulating renal cell death and inflammatory responses in mice. Int. Immunopharmacol., 38: 409-19. 2016.

48- MAGHREBI M. and RENNO W.M.: Genistein alleviates testicular ischemia and reperfusion injury-induced spermatogenic damage and oxidative stress by suppressing abnormal testicular matrix metalloproteinase system via the Notch 2/Jagged 1/Hes-1 and caspase-8 pathways. J. Physiol. Pharmacol., 67 (1): 129-37, 2016.

49- BO LI, YUE HE, LIANG XU, QIN HU, JUNJIA TANG, YUJIE CHEN, JIPING TANG, HUA FENG and JOHN H. ZHANG: Progranulin Reduced Neuronal Cell Death by Activation of Sortilin 1 Signaling Pathways After Subarachnoid Hemorrhage in Rats. Crit. Care Med. Aug., 43 (8): e304-e11, 2015. 


\section{البروجرانولين يحمى خصية الفئران من إصابات إعادة الآرواء}

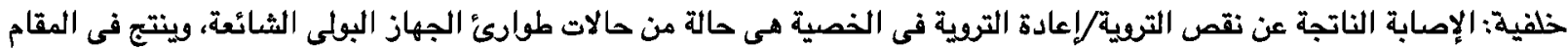

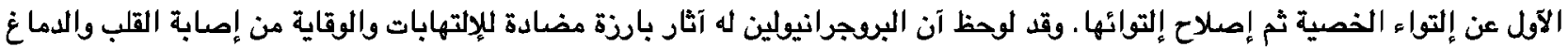

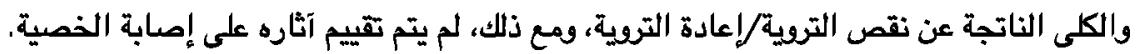

الهدف من الدراسة: دراسة تآثير البرجرانيولين على نقص التروية/إعادة التروية فى الخصية الناتج عن إلتواء الخصية/إصلاح الإلتواء والاليات المتوقعة لذلك.

المواد والطرق: فى هذه الدراسة، تم تقسيم الفئران إلى ع مجموعات: (1) مجموعة ضابطة، (Y) مجموعة نقص تروية الخصية/إعادة

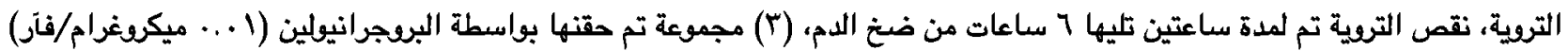

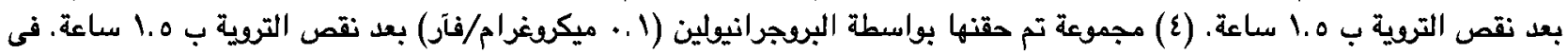

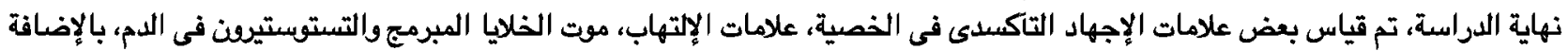
إلى دراسة باثولوجية لآنسجة الخصية.

النتبجة: لوحظت إنخفاضات كبيرة في مستويات هرمون التستوستيرون في الدم، ونشاط سوير آكسيد ديسميوتاز والجلوتاثين بيروكسيديز

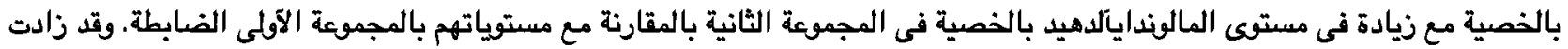

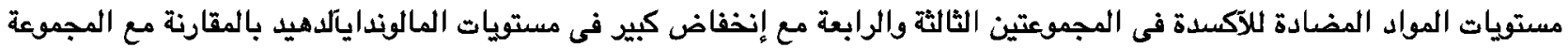

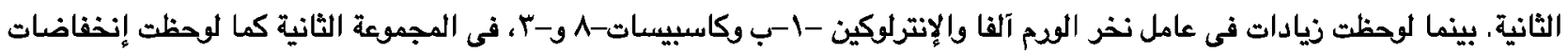

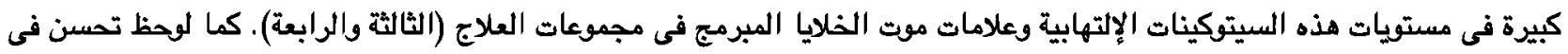

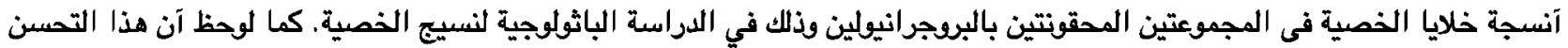
متدرج على حسب الجرعة حيث آن النتائج آفضل مع الجرعة الآعلى مما يدل على آن التحسن مرتبط بالتدرج في جرعة البروجرانيولين. الخلاصة: هذه النتائج تدل على آن البروجرانولين آدى بشكل كبير إلى تآثير وقائى ضد تلف آنسجة الخصية من خلال آليات مضادة

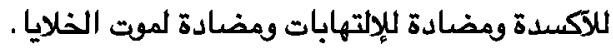

